\title{
On seismic investigations of the deep crustal structure according to the International Geophysical Year plan (*)
}

\author{
E. I. Galperin - I. P. Kosminskaya
}

The plan of the work of the USSR scientific institutions on the investigation of the crustal structure during the International Geophysical Year (IGY) comprises a study of the deep crustal structure in the transition zone between the Asian continent and the Pacific ocean in the region of the Okhotsk sea, the Kurile-Kamchatka arc and the adjoining parts of the Pacific ocean $\left({ }^{1,2}\right)$.

Since the Soviet Union did not carry out such work before, the Institute of the Physics of the Earth in collaboration with a number of other geophysical institutions (**) began preparatory investigations for the IGY. The purpose of these investigations is the working out of special instruments and methods of observation ensuring the conduction of the deep seismic sounding work at sea $(* * *)$.

The new methods should be based on the experience of the land deep seismic sounding being carried out in the USSR beginning with $1949\left(^{(3-10}\right)$ as well as on the experience of foreign investigations for the study of the oceanic crustal structure (12 $\left.{ }^{15}\right)$.

The first experiments for the development of the deep seismic sounding at sea were made in $\mathbf{1 9 5 6}$ at the Caspian sea.

When developing the methods and instruments mainly the use of deep refracted head waves was born in mind since the problem of

(*) Presented at the Utrecht Assembly of ESC, 1958.

(**) Including the Institute of the Oceanology, Academy of Sciences, USSR; the All-Union Research Institute of Geophysics; the Azerbaijan Oil Research Institute.

$\left({ }^{* * *}\right)$ By the method of the deep seismic sounding Gamburtzev, G. A. $\left({ }^{3}\right)$, its author meant the study of the crustal structure by seismic mothods using as in seismic prospecting special observation system ensuring the application of correlation principles for recognizing, tracing, and identifying seismic waves. 
the application of reflected waves for systematic study of the deep crustal structure is still in the process of experiments.

During this work special instruments were elaborated for recording deep seismic waves at distances up to $200-250 \mathrm{~km}$ from the point of shots of small power (about $100 \mathrm{~kg}$ of explosives).

The characteristic features of the of instruments for the deep seismic sounding at sea distinguishing them from the instruments for land investigations $\left({ }^{15}\right)$ are the application as receivers of seismic disturbances, of pressure transducers - hydrophones and special devices for recording high-frequency sound waves.

The methods of observation at sea by means of the DSS are different from those used for land investigations $\left({ }^{3,11}\right)$. The difference consists in the use of moving shot points and the one-point system of recording at sea instead of fixed shot points and many-point recording at the continuous or interval-continuous profiles at land. The more wide application of the correlation systems of observation including area surveys and the combining of sea observations with those at land distinguishes the developed methods from the English and American methods of sea seismic sounding investigation.

The peculiarity of the interpretation technique of sea DSS materials is the application of correlation principles for recognizing and tracing of groups of waves when analysing one-point seismograms $\left({ }^{16}\right)$ as is done in analysing many-point seismograms obtained from continuous and interval-continuous profiles with fixed shot points $\left(^{\circ}\right)$ and a wider application of various analysis methods of seismograms which are developed in seismic prospecting by the correlation refraction nethod $\left({ }^{1718}\right)$.

\section{Crustal structure of the central part of the Caspian sea.}

The development of DSS technique at sea was accompanied by the work for solving the geophysical problem of studving the crustal structure of the Central Caspian sea $\left(^{1}\right)$.

This region is of interest from the geological point of view. Here large structures of essentially different geological history, one - of the Epi-ffercynian Turkmen platform, the other-of the Caucasian folding $\left({ }^{20}\right)$, come in close contact with each other.

The profiles of DSS cross the Caspian sea and form a kind of net ensuring sufficiently detailed seismic observations. On records obtained in the Central Caspian sea three main groups of deep waves (fig. 1) are distinguished which correspond to discontinuities at different depths. 


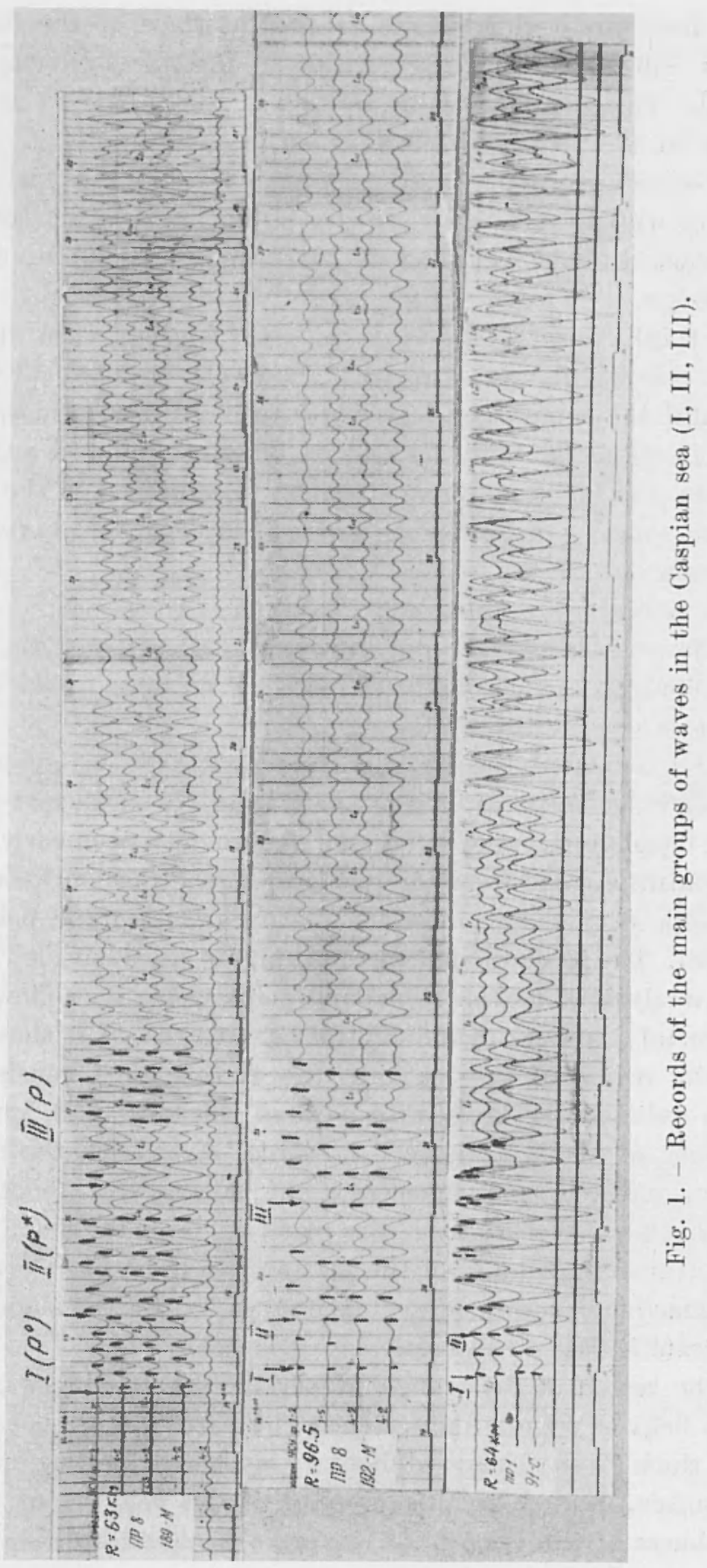


The first group corresponds to the interface of the crystal base or the so called granitic layer with the interface velocity of about $6 \mathrm{~km} / \mathrm{sec}$. This boundary is at the depth from $2 \mathrm{~km}$ on the platform to $20 \mathrm{~km}$ in the region of the Caspian trough.

The second group of waves corresponds to the interface of the basaltic layer with the interface velocity of $6.6 \mathrm{~km} / \mathrm{sec}$. The depth of the basaltic layer is about $15 \mathrm{~km}$ on the platform and $20-30 \mathrm{~km}$ in the region of the trough.

The third group is associated with the Mochorovicic discontinuity with the velocity about $8 \mathrm{~km} / \mathrm{sec}$. The depth is about $35-45 \mathrm{~km}$.

Besides the main deep-seated discontinuities a sufficiently steady interface in sediments with the velocity of about $5 \mathrm{~km} / \mathrm{sec}$ and the depth of 8-13 km was found as well as a group of interfaces in the upper part of the cross-section with interface velocities of $3.2-4.0 \mathrm{~km} / \mathrm{sec}$ and the depths from 3 to $7 \mathrm{~km}$.

The system of profiles was so complete that it made possible to draw maps with iso-depth lines of main interfaces (fig. 2).

The analysis of these maps shows that the relief of the deep-seated interfaces is complicated.

In the region of the Epi-Hercynian platform whose boundary is well outlined in the part of the shallow-seated surface of the crystal base, the deep interfaces (Conrad and Mochrovicic) are nearly horizontal. In the transition zone from the platform to the Caspian trough a steep abrupt slope of the base interface, the interface of the basaltic layer, is observed. The Mochorovicic discontinuity is relatively slowly lowering.

The analysis of cross-sections and maps yields the following scheme of the crustal structure of the Central Caspian sea, as is shown in fig. 3 .

In the region of the platform the earth's crust consists of three layers: a sedimentary layer with a small thickness $(2-3 \mathrm{~km})$ and with the velocity of about $3 \mathrm{~km} / \mathrm{sec}$, a granitic layer with the thickness of 10-15 km, and a basaltic layer with the thickness of about $20-25 \mathrm{~km}$. The thickness of the crust on the platform is about $30-35 \mathrm{~km}$.

The transition zone from the platform to the trough is characterized by a sharp increase of the sedimentary layer thickness and a decrease of the granitic layer thickness.

In the region of the trough proper the granitic layer is not found with the help of seisnfic data. Here the earth's crust consists of two layers: a thick (over $20 \mathrm{~km}$ ) sedimentary layer with a low average velocity $(3.5-4 \mathrm{~km} / \mathrm{sec}$.) and a basaltic layer with the velocity of $6.6 \mathrm{~km} / \mathrm{sec}$. The thickness of the crust is of the order of $40-45 \mathrm{~km}$. 


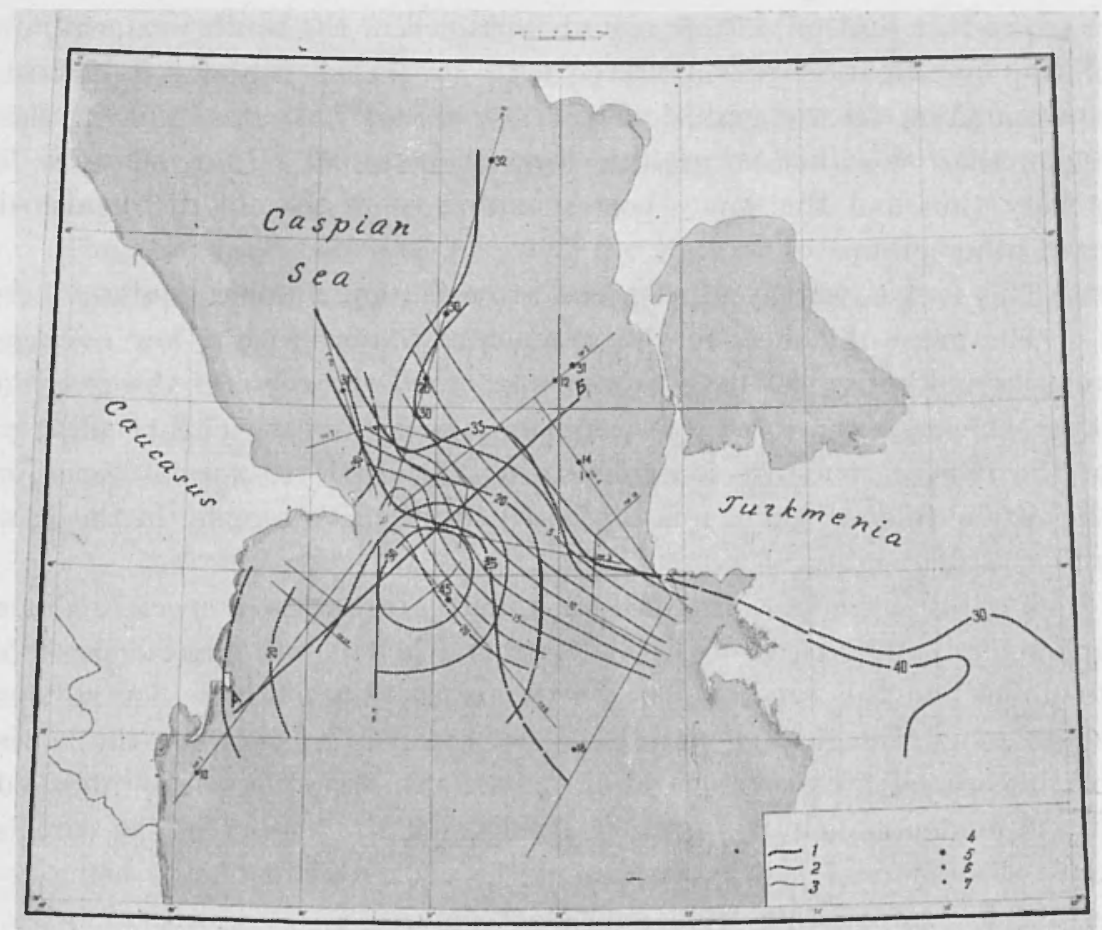

Figr. 2. - Maps of iso-depth lines of the main interfaces.

I. Isolines of the $M$ boundary, $-2 C$ boundary, -3 crystal base, 4 DSS profils, -5 Dephts $(\mathrm{km})$ of $M$ boundary, -6 . $C$ boundary, 7 crystal base.

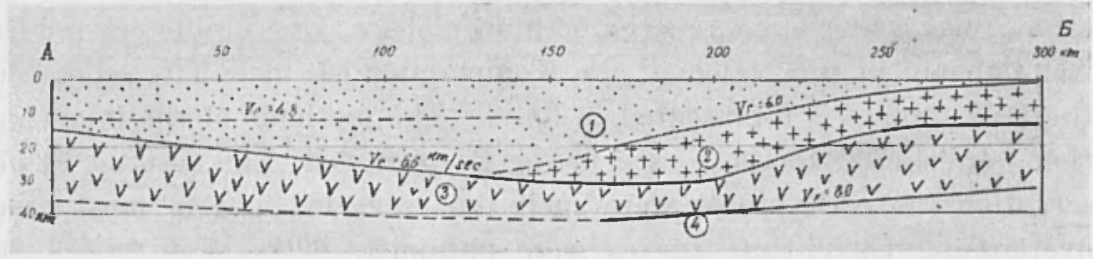

Fig. 3 - Schematic cross-section of the earth's crust for the central part. of the Caspian sea.

1 Sedimentary rocks with the average velocity of 3.5 to $4.0 \mathrm{~km} / \mathrm{sec}$ sec. - 2 Granitic layer $-6 \mathrm{~km} / \mathrm{sec}$ - 3 Basaltic layer $-6.6 \mathrm{~km} / \mathrm{sec}$. 4. Under-crust layer-8 $\mathrm{km} / \mathrm{sec}$. 
The fact that on seismic records obtained in the south-western part of the investigation region waves with the velocity about $6 \mathrm{~km} / \mathrm{sec}$. corresponding to the granitic layer are absent indicates that in this region there is either no granitic layer in its usual seismic sense or it is very thin and the waves corresponding to it are not distinguished from other groups of waves.

This fact is worthy of a special attention and further analysis.

The great thickness of the sedimentary layer with a low average velocity in the region of the absence or small thickness of the granitic layer which was indicated by seismic data is of interest. This peculiarity of the crustal structure is evidently characteristic to special zones of the Alpine folding which was subjected to intensive sagging in the past and is still sagging at present.

Further investigation of the crustal structure of such special regions and the adjoining parts of the platform and folding will make it possible to determine the types of the earth's crust characteristic for regions of different geological structure. When the relation between the types of the crustal cross-sections and the modern structures is established it will evidently help in future to reconstruct the history of the earth's crust development just as at present the geological history is being reestablished proceeding from geological data.

INVESTIGATIONS IN THE TRANSITION ZONE FROM THE ASIAN CONTINENT TO THE PACIFIC OCEAN.

The first experiments in this region were carried out as far back as $1956\left(^{*}\right)$.

The DSS profiles crossed the Okhotsk sea, the deep Kurile trough after which going out on to the oceanic plateau. One profile crossed the Aleutian arc in the region of the Kommandor islands. The scheme of the DSS profiles is represented in fig. 4 . The methods of the investigation were similar to those used in the Caspian sea. The systems of observations at each profile were such that reversed and in most cases overlapping travel-time curves were obtained.

The material of the expedition is now being interpreted. Some preliminary results are given below.

(*) The investigations were dirested by s. M. Zverev. 
The analysis of the waves on seismograms (fig. 5) showed that three groups can be distinguished among the initial waves: the first group $P^{\circ}$ with the apparent velocities of $V^{*}$ from 4 to $7 \mathrm{~km} / \mathrm{sec}$, the second group $P^{*}$ with $V^{*}$ from 6 to $8 \mathrm{~km} / \mathrm{sec}$, the third group $P$ with $W^{*}$ from 6 to $10 \mathrm{~km} / \mathrm{sec}$.

The boundary velocities $V_{r}$ which are determined from overlapping travel-time curves suggest that the first group $\mathrm{P}^{\circ}$ is associated with the

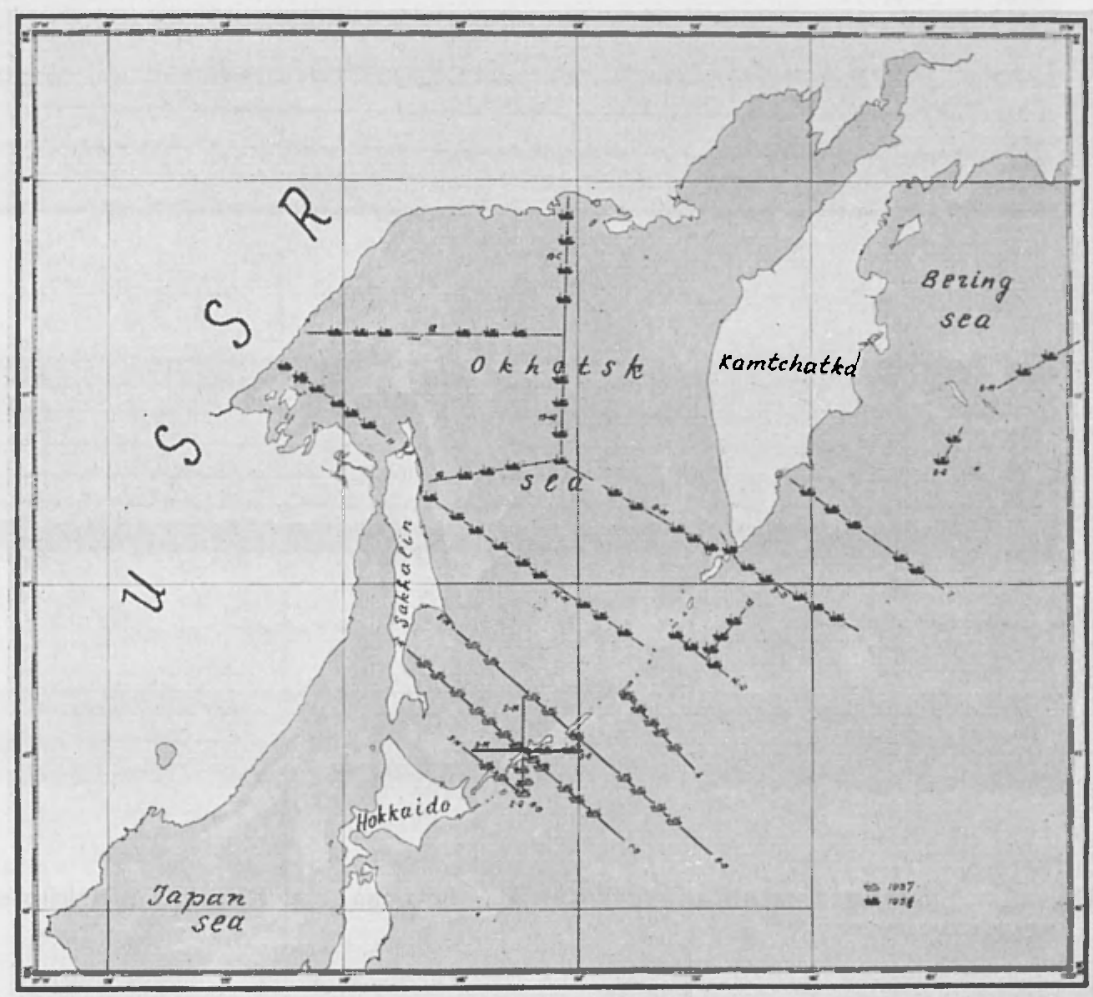

Fir. 4. - Scheme of the distribution of DSS profiles and recording stations.

boundaries in sediments $\left(V_{r}<5 \mathrm{~km} / \mathrm{sec}\right)$ and in the so-called granitic layer $\left(V_{r} \approx 6 \mathrm{~km} / \mathrm{sec}\right)$, the second one $P^{*}\left(V_{r}=6.5\right.$ to $7 \mathrm{~km} / \mathrm{sec}$. $)-$ with the boundaries in the basaltic layer, and the third one $P$ $\left(V_{r}=8 \mathrm{~km} / \mathrm{sec}\right)$ - with the Mochorovicic discontinuity.

The comparison of the travel-time curves of initial waves obtained in different regions permits to distinguish three main types of the trave I- 
time curves which differ as to the number of branches and the arrival time of the main waves (fig. 6).

The first type is oceanic observed in the region of the oceanic plateau to the east of the Kurile trough. It has two branches corresponding to $P^{*}$ and $P$ waves.
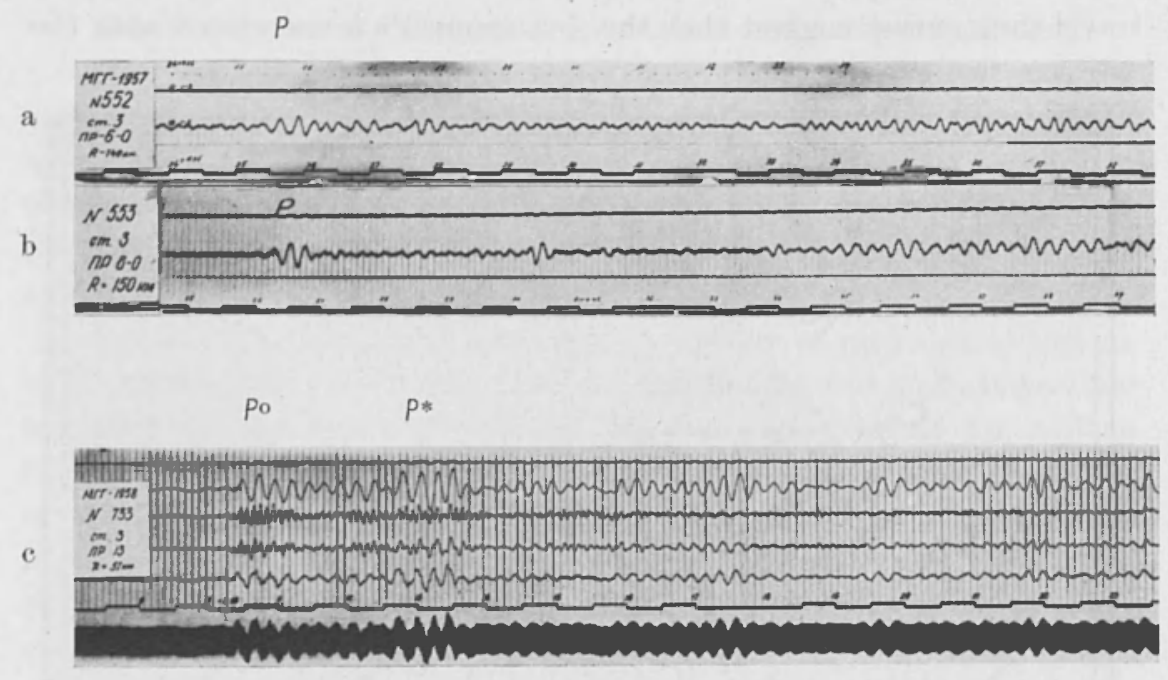

$P$

d

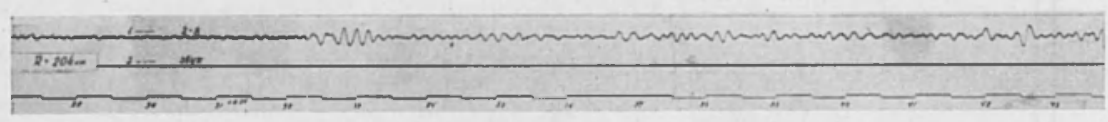

Fig. 5. - Seismograms obtained in the Pacific ocean (a, b) and the Okhotsk sea $(c, d)$.

The second is continental observed in the near-insular zones of the Kurile arc, in the near-shore zone of Kamchatka, in the Northern part of the Okhotsk sea. It has three branches corresponding to $P^{\circ}, P^{*}$, and $P$ waves. The times of the second type curve at a distance of $100 \mathrm{~km}$ from the shot point are greater by 4 to $6 \mathrm{sec}$ than those of the first type curve.

The third type is intermediate observed in the Southern deep part of the Okhotsk sea and the Bering sea. It has two branches correspond- 


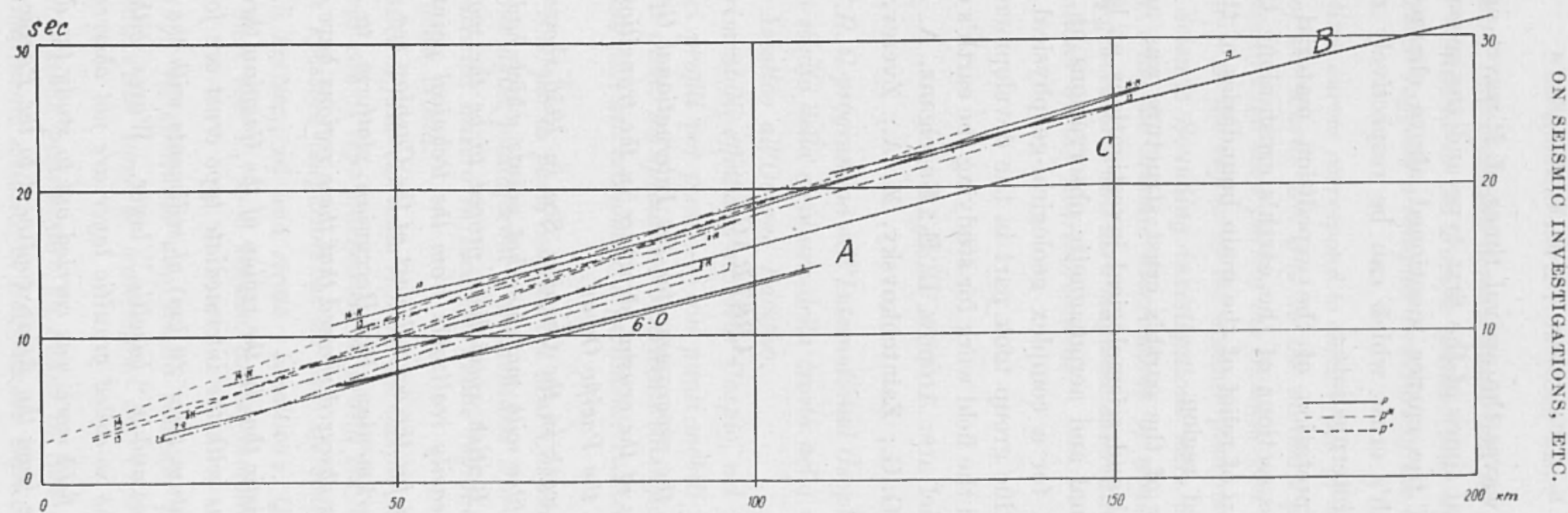

Fig. 6. - Oceanic (a), continental (b) and intermediate (c) types of travel - time curves. 
ing to $P^{*}$ and $P$ waves the arrival times of $P$ waves are intermediate between the arrival times of the first type and the second type curves.

The types of the curves mentioned above characterize different types of the earth's crust which can be respectively named oceanic, continental, and intermediate.

Further interpretation of the expedition material will permit to construct the cross-sections of the earth's crust along the profile lines and to draw a map of relief of the main boundaries of the earth's crust in the investigated region.

Seismic study of the earth's crust structure was accompanied by complex geological and seismological investigations at land, by hydrological, gravitational and aeromagnetic observations at sea. All these data will be used for a complex geological-geophysical interpretation.

A large scientific group took part in the development of DSS technique at sea and in the field work for studying the earth's crust structure. The main personnel are: Aronov, L. E.; Gagelganz, A. A.; Krakshina, R. M.; Mikhota, G. G.; Zaintchkovsky, M. A.; Zverev, S. M.; Weizmann, P. S.

\section{ABSTRACT}

In the USSR the programme for the International Geophysical Year envisaged the study of the crustal structure in the transition zone from the Asian continent to the Pacific Ocean.

Experimental work in the Caspian Sea in 1956 showed that the technique of point profiles with movable shot points which had been developed by American and British specialists proved to be the most economically advantageous and easily realizable from the technical point of view.

The DSS data for the central part of the Caspian sea where the transition from the Turkmenian Epi-Hercynian platform to the Caucasian geosynclinal zone is observed showed that these regions have different crustal structure.

It is characteristic that in the region of the Caspian through in the geosynctinal zone areas with the intermediate type crust are found which consists of a thick stratum (over $20 \mathrm{~km}$ ) of sediments with the average velocity of 3.0 to $3.5 \mathrm{~km} / \mathrm{sec}$ and $a$ "basaltic" layer. Waves with $V_{1} \approx 6 \mathrm{~km} / \mathrm{sec}$. corresponding to the so-called granitic layer are not observed here.

In 1957-1958 field work was carried out to study the deep structure of the transitions zone from the Asian continent to the Pacific. 
A preliminary interpretation demonstrated that for the transition zone from the Asian continent to the Pacific seismic data of various character were obtained, which suggests a complex structure of the earth's crust in this region.

The travel time curves correspond to three types of crust: continental on the islands of the Kurile Arc and in the northern part of the Okhotsk Sea; intermediate - in the deep part of the Okhotsk Sea and in the Bering Sea; and oceanic - in the region of the oceanic plateau.

The Deep Seismic Sounding investigations were conducted as single complex together with the seismic observations of weak local earthquakes (Hurup Island), gravimetric and aero-magnetic observations at sea and geological investigations of the nearshore areas.

\section{RIASSUNTO}

Nell'U.S.S.R. il programma dell'International Geophysical Year è stato progettato per lo studio della struttura della crosta nella zona di transizione dal Continente Asiatico all'Oceano Pacifico.

Lavori sperimentali, effettuati nel Mar Caspio, nel 1956, dimostrarono che la tecnica dei profili per punti - con punti mobili per il colpo - che era stata messa a punto da specialisti americani ed inglesi, era la più vantaggiosa dal punto di vista economico e facilmente realizzabile dal punto di vista tecnico.

I dati di D.S.S. per la parte centrale del Mar Caspio dove è stata osservata la transizione dalla piattaforma Turkmeniana Epi-Hercinia alla zona geosinclinale caucasica misero in luce che queste regioni hanno una struttura differente della crosta.

$\dot{E}$ caratteristico il fatto che nella regione del Caspio si trovino nella zona geosinclinale, aree con $i l$ tipo intermedio di crosta che è costituito da uno strato di grande spessore (superiore ai $20 \mathrm{~km}$ ) di sedimenti con velocità media di 3.0-3.5 km/sec., ed uno strato "basaltico". Qui non sono state invece osservate onde con $V_{1} \approx 6 \mathrm{~km} / \mathrm{sec}$. corrispondenti al cosidetto strato granitico.

Nel 195\%-1958 fu effettuato uno studio soltanto per determinare la struttura profonda della zona di transizione dal Continente Asiatico al Pacifico.

Una interpretazione preliminare ha messo in luce che per la zona di transizione dal Continente Asiatico al Pacifico son stati ottenuti dati sismici 
di vario carattere, che suggeriscono una complessa struttura della crosta terrestre in questa regione.

Le curve temporali corrispondono a tre tipi di crosta: continentale sulle Isole dell'Arco Curile e nella parte nord del Mare di Okhotsk; intermedia - nella parte profonda del Mare di Okhotsk e nel Mare di Bering; ed oceanica - nella regione della piattaforma oceanica.

Le ricerche di Sondaggio Sismico Profondo Sonoro furono effettuate, come un complesso unico, insieme con le osservazioni sismiche dei terremoti locali deboli (Hurup-Island), le osservazioni gravimetriche ed aeromagnetiche in mare e le ricerche geologiche delle zone lungo le sponde.

\section{REFERENCES}

(1) Ризниченко Ю. В., К изучению строения земной коры в период третьего Мезсдународного Геофизического Года, Изв. АН СССР, серия геофизическая, 2, (1957).

(2) Веицман П. С., ГАльПЕРЬин Е. И., Изучение строения земной коры в области перехода от Азиатского континента к Тихому океану. Информационныи бюллетень МГГ, 3, (1957).

(3) ГАмьУРЦЕв Г. А., Глубиниое сеисмическое зондирование земной коры. ДАНСССР, 87,6 , (1952).

(4) - Веицман П. С., Давыдова Н. И., Тулина ЮО. В. Глубинное сейсмическое зондирование земной коры на Северном Тянб-Шане. Бюлцетець Совета по сейсмолюгии АН СССР, 3, (1957).

(5) - - Осоденности строения земной коры в районе Северного Тянь-ІІІаня по данныгм глубиннодо свйсмического зондирования и сопоставление с данными zеологии, сеисмологии и гравиметрии, Боллетень Совета по сеисмологии АН CCCP, 3, (1957).

(') Веицманн П. С. Корреляция сейсмичедких волн при глубинном сейсмическом зондировании, Изв. АН СССР, сер геофиз. 12, (1957).

(7) - О результатах работ по глубинному сеисмическоту зондированию земнои коры в одном из районов Среднеи Азии. т. 2, 3, (1958).

(8) Veytsman P. S., Kosminskay a I. P., Riznichenko J. V., New evidence for the structure of the earth's crust and mountine roots in central Asia from data on seismie deep sounding. Publ. Bureau centr. seism. intern. tr. se. S. A., f. N 20.

(9) КосминСКАЯ И. ІІ., ТУЛина ІО. В. Опыт применвпия метода глубинного сеисмиского зондирования для изучения строения земной коры некоторых районов Западной Туркмении. Изв. АН СССР, серия геофизическая 7, (1957).

(10) РизничепкоЮ. В. Изучение строения земнои коры в СССР методом глубинного зондирования, геофиз. № геодез. т. 2, 3, (1958). 
(11) Bullard E. C., Gaskell I. F., Proc. Roy, Soc. A. 177, (1941).

(12) Ewing M. E., Suffou G. II., Officer C. B., Bull. Seismol. Soc. An., 44. $1,(1954)$.

(13) RaItT R. W., Bull. of the Geol. Am., 67, 12, (1956).

(14) Ewing I., Ewing M, Bull of the Geol. Soc. Am., 70, 3, (1959).

(15) АКсенович Г. И., ГАльПЕрин Е. И., ЗАИончковскии М. А., ОСновные особенности аппаратуры для глубинного сеисмического зондирования и результаты ее опробования, Изв. АИ СССР, серия геофизическая, I, (I957).

(16) ГАльПерин Е. И., КосминскАЯ И. П., ОСобенности методики глуоинного сейсмического зондирования на море, Изв. АН СССР, сер. геофизическая, 7, (1953).

(17) ГАМБУ РЦЕВ Г. А., РИЗИИченко Ю. В., БеРЗОН И. С., ЕПИНАтьевА А. М., НАСЕчНИК И. П., КОСминсКАЯ И. П., КАРУС Е. В., Корреляционный метод преломленныХ волн, Академиздат, 1952.

(18) Берзон И. С., Высокочастотная сеисмика, Академиздат, 1957.

(19) ГАГЕЛЬГАНЦ А. А., ГАлЫІерИі Е. И., КосмИСКАЯ И. П., КРАКШИНА Р. М., Строение земной коры иентральной части Каснийского моря по данным глубинного сеисмического зондирования, ДАН СССР, т. 123, 3, (1958).

(20) Соловьев В. Ф., Рельеф и строение Апиеронск. пол., Изв. АН СССР, сер. геол., 5, (1954).

(21) ГАльПЕРИН Е. И., Зверев С. М., ГорячеВ А. В., Геолого-геофизисеские исcлеdoвания земной коры в области перехода от Азиатского континента к Тихому океану, Издательство АН СССР, (1958). 